\title{
PENJADWALAN KARYAWAN \\ (APLIKASI METODE CYCLICAL SCHEDULING DI LAUNDRY ZONE)
}

\author{
Muhamad Cahyo Widyo Sulistyo \\ Fakultas Ilmu Administrasi, Universitas brawijaya \\ Email: widyo.sulistyo@gmail.com
}

\begin{abstract}
In this study, we will examine the use of cyclical scheduling in an effort to achieve competitive advantage. The use of cyclic scheduling systems is considered suitable because the cyclical scheduling system provides a fixed scheduling in a certain period of time. With a fixed schedule for some time, it is expected that the existing workers will be more proficient in doing their tasks. With the possibility to be transferred to another part, then a worker will have diverse expertise so that the company no longer needs to recruit more workers so that the costs that have become obstacles for small companies to progress can be suppressed. With a cyclical scheduling system, the workload that has been distributed less evenly, will become more evenly distributed because each worker will be given a work schedule that is adjusted to the number of consumer. From the results of the study, it is known that the workload of each worker is more evenly distributed, because each worker will get a day off on a day when the number of jobs is decreasing. Certainty of holidays and work schedule will make workers plan other activities outside the work. With this certainty, every change in schedule due to the personal interests of employees can be predicted more accurately.
\end{abstract}

Keywords: cyclical scheduling, competitive advantage, scheduling

\begin{abstract}
ABSTRAK
Dalam penelitian ini, akan diteliti tentang penggunaan sistem penjadwalan pekerja siklis atau cyclical scheduling dalam usaha untuk mencapai keunggulan kompetitif. Penggunaan sistem penjadwalan siklis dirasa cocok karena sistem penjadwalan siklis memberikan sebuah penjadwalan yang bersifat tetap dalam kurun waktu tertentu. Dengan penjadwalan yang tetap selama beberapa waktu, diharapkan pekerja yang ada akan semakin mahir dalam mengerjakan tugas-tugasnya. Dengan kemungkinan untuk di pindah tugaskan pada bagian yang lain, maka seorang pekerja akan memiliki keahlian yang beragam sehingga perusahaan tidak perlu lagi merekrut pekerja yang lebih banyak sehingga biaya yang selama ini menjadi kendala bagi perusahaan kecil untuk maju bisa ditekan. Dengan sistem penjadwalan siklis, beban kerja yang selama ini terdistribusikan kurang merata, akan menjadi semakin merata karena setiap pekerja akan diberikan jadwal kerja yang disesuaikan dengan jumlah permintaan konsumen. Dari hasil penelitian diketahui bahwa beban kerja dari masing-masing pekerja semakin merata, karena setiap pekerja akan mendapatkan jatah libur pada hari yang jumlah pekerjaan sedang berkurang. Kepastian akan hari libur dan jadwal masuk kerja ini akan membuat pekerja dapat merencanakan aktivitas yang lain di luar pekerjaan. Dengan kepastian ini pula, setiap perubahan jadwal akibat dari adanya kepentingan pribadi dari karyawan dapat diprediksikan dengan lebih akurat.
\end{abstract}

Kata kunci: Cyclical scheduling, Competitive advantage, Penjadwalan karyawan, 


\section{PENDAHULUAN}

Teknologi adalah sebuah alat bantu atau penunjang dari aktivitas manusia. Peran teknologi tidak hanya sebatas pada membantu manusia dalam melaksanakan aktivitas kantor atau pendidikan, namun sudah mencapai tahap membantu dalam aktivitas pribadi. Mencuci piring, kini tidak lagi dilakukan oleh pembantu atau individu yang bersangkutan, begitu pula dengan aktivitas mencuci pakaian, kini mesin cuci mengambil alih peran manusia, meskipun tidak sepenuhnya. Tidak hanya sebatas membantu secara individual, teknologi juga digunakan dalam skala korporat untuk menunjang proses produksinya.

Sebagai sebuah organisasi jasa, sumber daya manusia adalah hal yang perlu diperhatikan oleh pemilik laundry. Pemberian pelatihan, standar gaji yang sesuai, dan juga kondisi lingkungan kerja yang manusiawi adalah beberapa faktor yang harus dipenuhi oleh perusahaan dalam memanfaatkan tenaga manusia. Pemberian jasa yang berkualitas adalah tujuan dari setiap perusahaan jasa, tak terkecuali perusahaan jasa pencucian. Banyak faktor yang akan dijadikan dasar bagi konsumen untuk memilih pelayanan rumah sakit, antara lain: kebersihan pakaian, kebersihan tempat, keutuhan pakaian, kesigapan personel, keramahan, dan juga cara melayani komplain atau keluhan pelanggan adalah beberapa faktor yang akan menjamin kesuksesan sebuah jasa pencucian. Kottler mengatakan, perusahaan jasa yang mampu memuaskan konsumen akan mendapatkan loyalitas dari konsumen, hal ini disebabkan oleh switching cost atau biaya untuk berpindah ke penyedia jasa yang lain. Konsumen akan mencari penyedia jasa yang sanggup memenuhi kebutuhan konsumen tersebut, perpindahan dari satu penyedia jasa ke penyedia jasa lainnya relatif tidak membutuhkan biaya, karena sangat jarang konsumen laundry yang tergabung ke dalam keanggotaan sebuah usaha pencucian, hal ini menjadikan kualitas layanan jasa harus diberikan dengan sepenuh hati kepada konsumen (Kottler, 2006). Kepercayaan dan juga pengalaman dari konsumen jasa adalah faktor penting bagi kelangsungan hidup perusahaan jasa (Kottler, 2006). Konsumen jasa, dalam menentukan kualitas jasa bergantung pada omongan konsumen lain (word of mouth) daripada iklan perusahaan jasa tersebut, selain itu harga, personel yang melayani, dan kondisi fisik atau lingkungan adalah indikator yang digunakan konsumen dalam menentukan kualitas dari jasa (Kottler, 2006). Dengan mengandalkan promosi lewat mulut ke mulut, maka kualitas dari jasa yang diberikan harus benar-benar diperhatikan dengan serius. Dalam bisnis jasa yang mengandalkan konsumen, loyalitas konsumen terhadap merek harus dijaga demi kelangsungan hidup perusahaan. Dengan loyalitas yang tinggi maka penilaian konsumen terhadap merek akan positif, dan hal ini akan membuat setiap keluhan yang terjadi di konsumen bisa diselesaikan dengan cara yang terbaik bagi kedua belah pihak. Manusia sebagai operator dari mesin cuci dan mesin pengering, adalah penentu keberhasilan usaha laundry untuk menciptakan kepuasan pada diri pelanggan yang menggunakan jasanya. Salah satu cara yang dapat ditempuh agar karyawan dapat memberikan tenaganya dengan maksimal adalah dengan mengatur hari kerja sedemikian rupa sehingga memungkinkan pekerja untuk memulihkan tenaganya yang terkuras karena kegiatan operasi sehari-hari, atau dengan kata lain menyusun jadwal yang baik adalah keharusan bagi usaha jasa. Berbeda dengan perusahaan manufaktur, penjadwalan yang dilakukan di perusahaan jasa lebih mengarah kepada susunan kepegawaian (Heizer et al, 2005). Perbedaan lain antara perusahaan jasa dengan perusahaan manufaktur adalah, jasa lebih padat karya, permintaan akan pegawai bervariasi, dan perusahaan jasa jarang yang menyimpan persediaan (Heizer et al, 2005). Dengan mengatur hari kerja bagi tiap-tiap pekerja, maka diharapkan tujuan dari perusahaan dapat tercapai.

Selain sebagai alat untuk mencapai tujuan perusahaan, sumber daya manusia juga dapat dijadikan sebagai salah satu strategi untuk mencapai keunggulan kompetitif dalam persaingannya dengan perusahaan lain. Penggunaan sumberdaya manusia sebagai strategi, haruslah memenuhi kriteria: pertama, sumberdaya manusia yang ada digunakan secara efisien namun tetap dalam batas yang sesuai dengan keputusan manajemen operasi yang lainnya, dan kedua adalah terdapat kualitas lingkungan kerja yang manusiawi yang menjunjung komitmen dan kepercayaan antara manajemen dengan pekerja (Heizer et al, 2006). 
Penggunaan tenaga manusia dalam sebuah perusahaan, selalu berhadapan dengan hambatan dari kegiatan operasi dalam perusahaan yang bersangkutan. Sebagai contoh, produk mix akan mempengaruhi keputusan mengenai penggunaan pekerja musiman dan juga stabilitas kerja, teknologi dan juga proses kerja akan mempengaruhi keputusan mengenai keselamatan kerja. Karyawan juga harus didukung dengan lingkungan kerja yang mendukung, karyawan bukan diperlakukan sebagai alat atau aset bagi perusahaan. Hubungan antara pihak pimpinan dan juga karyawan harus dilandasi oleh rasa saling percaya dan terdapat komitmen untuk saling mendukung (Heizer et al, 2006). Perasaan saling mendukung akan memudahkan perusahaan dalam mencapai tujuan yang telah dicanangkan, tanpa adanya dukungan dari kedua belah pihak, tujuan perusahaan hanya akan menjadi beban bagi salah satu pihak. Perasaan saling mendukung, juga diperlukan bagi perusahaan dalam pertempurannya dengan perusahaan lain.

Dari segi persaingan, dengan jumlah pemain yang banyak, dukungan dari strategi yang tepat adalah faktor lain yang akan mendukung keberhasilan sebuah perusahaan. Salah satu strategi yang kerap dipraktekkan adalah strategi menurunkan harga, strategi ini akan menguntungkan perusahaan dalam jangka pendek saja, sebaliknya dalam jangka panjang keuntungan perusahaan dan juga keuntungan perusahaan lain akan turun (Besanko et al, 2007). Perang harga dalam bisnis laundry hanya akan membuat perusahaan menyakiti dirinya sendiri, biaya operasional, biaya material pendukung seperti sabun cuci dan obat pewangi, serta biayabiaya lain yang harus ditanggung akan memberikan beban berat kepada pemilik bisnis. Keuntungan dari penerapan strategi menurunkan harga ini hanya akan diperoleh apabila ukuran atau jumlah konsumen banyak (Besanko et al, 2007), dalam sebuah bisnis jasa yang tergantung pada musim, jumlah konsumen akan selalu bervariasi sesuai dengan kondisi lingkungan. Dalam era yang membebaskan konsumen untuk mendapatkan informasi tentang suatu produk atau jasa seluas-luasnya, strategi harga murah belum tentu menjadikan konsumen berpaling kepada perusahaan yang memberikan harga murah tersebut. Banyak pertimbangan yang dilakukan oleh konsumen sebelum memutuskan untuk berganti ke penyedia jasa atau produk yang lain. Dalam bidang jasa, kualitas pelayanan, kesigapan operator, keramahan, kebersihan tempat dan promosi dari mulut konsumen yang lain adalah faktor yang akan menentukan loyalitas konsumen terhadap penyedia jasa yang bersangkutan. Sebuah keunggulan kompetitif adalah faktor penting bagi sebuah perusahaan baik jasa maupun manufaktur untuk dapat bertahan di era persaingan yang ketat ini.

Teknik pengaturan shift siklus ini memberikan keuntungan jadwal kerja yang adil bagi masing-masing pekerja. Tidak akan ada seorang pekerja yang mengalami jam kerja yang berlebih (Maenhout et al, 2006). Setiap pekerja akan bekerja pada bidang yang sama atau tempat yang sama. Dengan mengaplikasikan sistem ini, maka akan terbentuk sebuah kondisi kerja yang kondusif, setiap pekerja mengetahui dengan pasti apa yang harus dikerjakan, pembagian beban kerja yang adil, serta setiap pekerja mengetahui jadwal kerja mereka jauh-jauh hari (Maenhout et al, 2006). Cyclical scheduling akan membantu karyawan laundry untuk bekerja lebih efektif, karena setiap pekerja akan memegang tanggung jawab yang sama setiap harinya, pekerja bagian kasir akan tetap menjadi kasir, dan pekerja di bagian setrika akan tetap menangani masalah setrika. Selain itu dengan dibentuknya jadwal kerja jauh hari, setiap karyawan akan dapat dengan mudah mengatur jadwal kerjanya. Berdasarkan permasalahan yang disebutkan di atas, maka peneliti tertarik untuk meneliti tentang penetapan jadwal karyawan yang dihubungkan dengan ketepatan pemenuhan pesanan pelanggan.

\section{KAJIAN PUSTAKA JASA}

Kotler merumuskan jasa sebagai," A serve is any act of performance that one party can offer to another that is essentially intangible and does not result in the ownership of anything. Is production may or may not be tied to a physical product" (Kotler, 2000). Pengertian mengenai jasa juga diungkapkan oleh Lovelock yang mengartikan jasa sebagai "services are economic activities that create value and provide benefits for customer at specific times and places, as a result of bringing about a desired change in-or an behalf of-the recepient of the services". Apabila pernyataan Lovelock tersebut diterjemahkan akan 
menjadi, sebuah jasa adalah aktivitas yang memberikan nilai tambah dan juga keuntungan kepada konsumen pada waktu dan juga tempat yang spesifik. Dalam pernyataannya, Lovelock menyinggung masalah benefit, yang dimaksud dengan benefit adalah an advantage or gain that customer obtain from performance of a service or a use of a physical goods (Lovelock et al, 2002). Perusahaan dapat menghasilkan barang atau jasa, dan masing-masing memiliki karakteristik yang berbeda satu dengan yang lainnya, adapun karakteristik dari jasa adalah:

a. Tidak berwujud, jasa merupakan sesuatu yang tidak memiliki wujud, tidak dapat dilihat, tidak dapat didengar atau dicium sebelum jasa tersebut dibeli atau dikonsumsi oleh konsumen.

b. Tidak dapat dipisahkan, maksudnya adalah jasa dihasilkan dan dikonsumsi secara bersamaan. Interaksi antara penyedia jasa dan konsumen adalah ciri khusus dari produk jasa ini.

c. Variabilitas, artinya adalah jasa sangat bervariasi tergantung pada siapa yang menyediakan dan kapan serta dimana jasa tersebut dilakukan. Sehingga industri jasa sangat tidak mungkin untuk menghasilkan kualitas yang sama.

d. Tidak tahan lama, jasa tidak dapat disimpan dan memiliki permintaan yang berfluktuasi. Permintaan yang berfluktuasi ini terjadi karena beberapa kondisi seperti liburan, resesi ekonomi, kondisi alam, dan juga tingkat persaingan yang terjadi.

\section{Strategi Pemasaran Jasa}

Dalam era yang sangat ketat persaingannya ini, sebuah perusahaan dituntut untuk bekerja secara optimal. Perusahaan tidak lagi dapat mengandalkan keberhasilannya kepada efektivitas dalam kegiatan operasionalnya saja. Marketing atau kegiatan pemasaran juga memegang peran yang tak kalah pentingnya (Lovelock et al, 2002). Output atau produk jasa harus disesuaikan dengan keinginan dari konsumen, harga yang ditetapkan harus realistis, jalur distribusi yang dipilih harus memberikan kenyamanan, dan juga promosi yang aktif adalah beberapa faktor yang harus diperhatikan oleh pihak manajemen di perusahaan jasa.

Dalam bisnis jasa, terdapat banyak sekali elemen yang terkait dengan produk jasa. Sebagai contoh, pelanggan menggunakan kereta api dengan melihat apa yang tampak, seperti keramahan petugas, interior, kebersihan toilet dan sebagainya. Sehingga dengan hasil ini kualitas bisnis jasa dipengaruhi oleh sekumpulan elemen yang berubah-ubah. Gronroos dalam kotler, 1997, menyatakan bahwa pemasaran jasa terletak pada pemasaran internal dan pemasaran eksternal serta pemasaran interaktif yang dilakukan oleh perusahaan. Pemasaran eksternal menggambarkan tentang pekerjaan normal yang dilakukan perusahaan untuk menyiapkan, menetapkan harga dan mendistribusikan serta mempromosikan jasa tersebut kepada pelanggan. Pemasaran internal adalah pekerjaan yang dilakukan oleh perusahaan untuk melatih dan memotivasi karyawan agar mampu memberikan pelayanan terbaik. Sedangkan pemasaran interaktif adalah pemasaran yang menggambarkan keahlian karyawan dalam melayani klien atau konsumen. Klasifikasi tingkat kualitas jasa:

a. tinggi dalam kualitas pencarian, yaitu karakteristik yang dapat dievaluasi pembeli sebelum melakukan pembelian. Contoh pakaian, perhiasan, perabot rumah tangga, perumahan, mobil dan lain sebagainya.

b. tinggi dalam kualitas pengalaman, yaitu karakteristik yang dapat dievaluasi pembeli setelah melakukan pembelian. Contoh makan di restoran, liburan dan transportasi.

c. tinggi dalam kualitas kepercayaan, yaitu karakteristik yang sulit dievaluasi pembeli bahkan setelah menggunakannya, contoh reparasi tv, jasa hukum, reparasi mobil, diagnosa medis dan lain sebagainya.

\section{Perencanaan Kapasitas Jasa}

Sebagai sebuah perusahaan jasa, pemilik pegawai rumah sakit tentu telah memikirkan kapasitas dari pelayanan rumah sakit yang dioperasikannya. Kapasitas adalah kemampuan untuk memegang, menyimpan, menerima, atau mengakomodasi (Chase et al, 2004). Dalam lingkup bisnis, kapasitas diartikan sebagai kemampuan sistem produksi untuk menerima atau memproduksi output dalam kurun waktu tertentu. Dalam bidang jasa, kapasitas adalah berapa banyak konsumen yang dapat dilayani mulai pukul 8 pagi hingga 1 siang. 
Perencanaan kapasitas baik di perusahaan manufaktur maupun di perusahaan jasa, dapat digambarkan ke dalam tiga horison waktu. Ketiga horison tersebut adalah jangka panjang, jangka menengah dan jangka pendek (Heizer et al, 2006).

Waktu adalah hal yang harus diperhatikan dalam menentukan kapasitas dari perusahaan jasa. Tidak seperti perusahaan manufaktur yang produknya dapat disimpan untuk dinikmati atau dikonsumsi kemudian, produk jasa harus segera dikonsumsi sesaat setelah diproduksi. Dengan karakter seperti ini, maka kemampuan untuk memproduksi jasa pada saat pesanan atau permintaan akan jasa masuk adalah hal yang mutlak. Sebagai contoh, tiket pesawat yang telah dibeli untuk tanggal tertentu, harus dinikmati sesuai dengan tanggal yang tercantum, tidak dapat dinikmati sebelum atau sesudah tanggal yang tercantum dalam tiket.

Lokasi, adalah hal yang menentukan dalam bisnis jasa. Perusahaan manufaktur akan dapat mendistribusikan produknya meskipun lokasi pabriknya jauh dari konsumen, namun untuk perusahaan jasa, semakin dekat lokasi perusahaan dengan konsumen maka akan semakin besar kemungkinan perusahaan jasa tersebut untuk mendapatkan konsumen. Sebagai contoh adalah rental mobil yang ada di Solo tidak akan mendapatkan konsumen masyarakat Yogyakarta, karena lokasinya terlalu jauh untuk mengantarkan permintaan konsumen ke tempat tujuan.

Permintaan yang berubah, dalam jasa permintaan sering kali lebih fluktuatif daripada permintaan produk manufaktur (Chase et al, 2004). Alasan yang mendasarinya adalah, pertama, jasa tidak dapat disimpan sehingga penggunaan persediaan untuk membantu memenuhi permintaan yang ada. Kedua, adalah konsumen berinteraksi langsung dengan sistem produksi, setiap konsumen tentu memiliki pilihan atau preferensi tentang jasa yang ingin dinikmati. Karena keinginan konsumen yang beragam, dampak yang ditimbulkan adalah waktu untuk melayani keinginan konsumen tersebut yang berbeda, semakin bervariasi jasa yang diberikan akan semakin besar kapasitas yang dibutuhkan untuk memenuhi permintaan konsumen tersebut. Alasan ketiga adalah, jasa seringkali dipengaruhi oleh perilaku konsumen. Pada musim hujan bisa jadi bisnis pencucian baju menjadi bisnis yang paling menguntungkan, namun pada saat musim panas mungkin saja bisnis pencucian pakaian menjadi bisnis yang kurang menguntungkan.

\section{Jenis Penjadwalan}

Penjadwalan dapat dibagi berdasarkan jangka waktunya menjadi penjadwalan jangka panjang, penjadwalan jangka menengah dan penjadwalan jangka pendek (Heizer et al, 2006). Sedangkan berdasarkan pada jenis perusahaan yang mengaplikasikan penjadwalan, terdapat dua macam yaitu penjadwalan di perusahaan manufaktur dan penjadwalan di perusahaan jasa (Pinedo et al, 2004). Proses penjadwalan akan berpengaruh pada pengambil keputusan, keputusan yang berkaitan dengan perencanaan jangka panjang akan menjadi tanggung jawab dari manajemen puncak, hal ini disebabkan karena perencanaan jangka panjang berbicara tentang perencanaan perusahaan selama satu tahun mendatang dan bahkan lebih dari satu tahun. Perencanaan jangka panjang mencakup kegiatan seperti: riset dan pengembangan, perencanaan produk baru, investasi, dan kegiatan untuk merencanakan pengembangan fasilitas atau pabrik (Heizer et al, 2006).

\section{Pembebanan Pekerjaan}

Pembebanan pekerjaan atau yang juga disebut dengan istilah loading jobs adalah aktivitas untuk menempatkan pekerjaan yang ada kepada sel kerja atau pusat pemrosesan (Heizer et al, 2006). Manajer operasi melakukan penugasan pekerjaan ke dalam sel kerja tertentu dengan tujuan agar biaya, waktu menganggur, atau waktu penyelesaian pekerjaan tetap pada level yang paling minimum. Loading jobs ke dalam sebuah sel kerja dapat dilihat dalam dua teknik, yang pertama adalah pendekatan yang berorientasi kepada kapasitas dan pendekatan yang kedua adalah melihat penugasan pekerjaan yang spesifik ke dalam sebuah sel kerja (Heizer et al, 2006). Pendekatan yang pertama dapat dievlauasi menggunakan teknik yang lebih dikenal sebagai teknik input-output, sedangkan teknik yang kedua dapat dinilai dengan menggunakan metode gantt chart dan juga assignment method dengan menggunakan programasi linear (Heizer et al, 2006). 


\section{Penjadwalan Karyawan Metode Cyclical Scheduling}

Salah satu masalah yang timbul dalam menjadwalkan karyawan adalah masalah penjadwalan siklikal (Pinedo et al, 2004). Penjadwalan siklikal ini bertujuan untuk meminimalkan biaya yang dikeluarkan oleh perusahaan dalam menggaji karyawan. Biaya yang dikeluarkan tersebut adalah biaya untuk menugaskan sejumlah pekerja ke dalam satu periode siklikal sehingga jumlah pekerja sesuai dengan beban kerja yang dihadapi. Setiap pekerja ditempatkan dalam shift atau jam kerja yang terus-menerus selama beberapa minggu dan mendapatkan hari libur di hari lainnya (Pinedo et al, 2004).

Teknik pengaturan shift siklus ini memberikan keuntungan jadwal kerja yang adil bagi masing-masing pekerja. Tidak ada seorang pekerja yang mengalami jam kerja yang berlebih (Maenhout et al, 2006). Setiap pekerja akan bekerja pada bidang yang sama atau tempat yang sama selama beberapa periode waktu. Dengan mengaplikasikan sistem ini, maka akan terbentuk sebuah kondisi kerja yang kondusif, setiap pekerja mengetahui dengan pasti apa yang harus dikerjakan, pembagian beban kerja yang adil, serta setiap pekerja mengetahui jadwal kerja mereka jauh-jauh hari (Maenhout et al, 2006). Cyclical scheduing akan membantu karyawan laundry untuk bekerja lebih efektif, karena setiap pekerja akan memegang tanggung jawab yang sama setiap harinya, pekerja bagian kasir akan tetap menjadi kasir, dan pekerja di bagian setrika akan tetap menangani masalah setrika. Selain itu dengan dibentuknya jadwal kerja jauh hari, setiap karyawan akan dapat dengan mudah mengatur jadwal kerjanya. Dengan mengatur dan mengetahui jadwal kerjanya, maka diharapkan setiap pekerja akan mematuhi jadwal yang telah dibuatnya dengan penuh tanggung jawab, hal ini bisa juga dikatakan sebagai upaya untuk mengurangi jumlah ketidakhadiran karyawan pada jam kerja yang telah ditentukan.

Namun di balik jadwal yang menugaskan karyawan untuk menangani masalah yang sama selama beberapa periode, permasalahan yang timbul adalah jadwal yang terbentuk tidak fleksibel. Kakunya jadwal siklikal ini akan terlihat pada saat berhadapan dengan perubahan pada aturan ketenagakerjaan, permintaan akan tenaga kerja yang berubah-ubah, dan juga keinginan pekerja yang berubah-ubah (Burke et al, 2004, dalam Maenhout et al, 2006). Lebih lanjut Burke mengatakan bahwa dengan menerapkan jadwal kerja siklikal, sebuah perusahaan kehilangan fleksibilitasnya pada saat berhadapan dengan kebutuhan akan pekerja yang berubah-ubah dan juga pada saat karyawan mengungkapkan keinginan atau preferensi mereka dalam bekerja.

Penggunaan jadwal siklikal ini dapat disesuaikan dengan tujuan dari penyedia jasa. Perusahaan jasa akan selalu tergantung pada permintaan konsumen, dalam dunia nyata permintaan konsumen seringkali bergerak naik turun atau fluktuatif. Penjadwalan siklikal ini dapat digunakan untuk meminimalkan jumlah pekerja yang menangani operasional harian. Dengan jumlah pekerja yang minimal dalam artian pekerja yang hadir disesuaikan dengan permintaan atau pekerjaan yang ditangani hari itu (Pinedo et al, 1999), maka perusahaan akan mengeluarkan biaya yang kecil namun efektivitas pekerjaan meningkat karena ukuran dari karyawan yang kecil.

Penjadwalan siklikal juga dapat diterapkan untuk mengatur hari libur karyawan (Pinedo et al, 1999). Setiap organisasi atau perusahaan tentu sudah menentukan kegiatan operasinya dengan sangat cermat. Penetapan tersebut salah satunya didasarkan pada jumlah pesanan atau target penjualan yang telah ditetapkan dalam rencana jangka menengah perusahaan. Dalam sebuah perusahaan yang mengharuskan pekerja untuk bekerja pada hari Sabtu dan Minggu, penetapan jadwal harus dibuat seadil mungkin, sehingga setiap karyawan merasakan beban yang sama. Penetapan jadwal ini juga terkait dengan isu gaji yang harus dibayarkan oleh perusahaan, pada umumnya perusahaan akan menggaji karyawan lebih mahal pada hari libur.

\section{METODE PENELITIAN}

Penelitian tentang penjadwalan pekerja untuk mengatur hari libur dan hari kerja karyawan ini, mengambil desain penelitian eksplorasi. Dalam penelitian ini, peneliti memilih menggunakan penelitian deskriptif untuk menjelaskan fenomena atau permasalahan yang dihadapi oleh manajemen atau pemangku kebijakan dalam menjadwalkan karyawannya dan 
menggabungkannya dengan teknik kuantitatif untuk menentukan hari libur dan jam kerja bagi masing-masing karyawan pegawai rumah sakit. Desain penelitian eksplorasi dipilih karena tema penelitian yang diangkat tergolong baru, penelitian-penelitian yang sejenis mengambil tempat di rumah sakit atau maskapai penerbangan.

\section{Metode Analisis Data}

Berdasarkan data yang diperoleh, maka analisis data dalam penelitian ini menggunakan metode analisis kualitatif. Analisis kualitatif ini dilakukan dengan mengolah data yang diperoleh dari pihak manajemen perusahaan dalam penelitian ini pihak manajemen diwakili oleh pemegang waralaba. Penjabaran secara kualitatif ini dilakukan untuk mengungkap proses operasi dari waralaba pegawai rumah sakit Condong Catur. Selain itu proses penjabaran secara kualitatif ini akan menjelaskan permasalahan yang terjadi dalam penjadwalan yang dilakukan di waralaba pegawai rumah sakit.

Untuk menganalisis data tentang penjadwalan karyawan, metode penjadwalan siklikal akan digunakan dalam penelitian ini. Adapun langkah-langkah untuk menentukan penjadwalan dengan metode siklikal adalah sebagai berikut:

a. Tentukan jumlah karyawan maksimum setiap hari dalam satu minggu.

b. Lingkari dua hari berurutan yang memiliki permintaan paling kecil dari tiap-tiap karyawan. Hari yang dilingkari adalah hari libur bagi karyawan pertama. Dalam tabel di bawah hari libur karyawan tidak dilingkari melainkan diberi warna yang berbeda.

c. Setelah hari libur bagi karyawan pertama diketahui, kurangkan hari lain yang tidak dilingkari 1 angka, pengurangan ini tidak berlaku bagi hari yang sudah dilingkari.

d. Analisis dua hari berurutan di baris yang baru dengan jumlah yang paling sedikit, lingkari dan hari tersebut akan menjadi hari libur bagi karyawan yang bersangkutan.

e. Lakukan langkah ke tiga dan ke empat di atas hingga kebutuhan akan karyawan dapat terpenuhi. Untuk lebih jelasnya tabel berikut akan menjelaskan langkah-langkah dalam menyusun hari libur bagi karyawan.
Simulasi bagaimana metode ini dilakukan dapat dilihat di tabel 1, diketahui bahwa kebutuhan akan karyawan adalah dua orang. Satu orang karyawan akan dibutuhkan untuk menutupi kebutuhan karyawan di hari Minggu. Kebutuhan satu karyawan di hari Minggu dapat dipenuhi dengan dua cara, cara pertama adalah dengan merekrut tenaga lepas atau part-time employee. Sedangkan cara kedua adalah dengan mengangkat tenaga kerja tetap. Pemenuhan tenaga kerja dengan mengangakat pegawai tetap akan membuat tenaga kerja tambahan tersebut akan memiliki waktu libur berurutan selain hari sabtu, pegawai tambahan tersebut akan dibutuhkan tenaganya hanya pada hari Sabtu, dilihat dari sisi biaya pengangkatan tenaga tambahan sebagai pegawai tetap akan membuat jumlah karyawan yang dibutuhkan tiap harinya mengalami kelebihan sebanyak satu orang.

Setelah kebutuhan akan karyawan diketahui, maka langkah selanjutnya adalah menghitung pengaruh keputusan perekrutan karyawan dalam biaya operasional. Biaya yang dikeluarkan akan menentukan harga dari produk yang diproduksi. sebagai perusahaan jasa, memberikan jasa yang berkualitas adalah hal yang perlu dilakukan. Dengan berkompetisi di bidang laundry kiloan yang menuntut harga murah, maka pembengkakan biaya operasional akan menyebabkan harga yang mahal, dan pada akhirnya akan membuat konsumen berpaling kepada penyedia jasa yang lain.

\section{PEMBAHASAN}

\section{Penjadwalan Karyawan 24 Jam}

Laundry Zone 24 jam memiliki waktu operasi yang lebih lama dan tentu saja jumlah karyawan yang dimilikinya pun lebih banyak daripada Laundry Zone yang beroperasi 12 jam. Dengan mengerjakan kapasitas yang lebih besar, maka pembagian tugas yang adil akan menjadi sebuah keuntungan bagi Laundry Zone untuk berkompetisi. Dalam satu bulan jumlah cucian yang masuk dapat mencapai $5000 \mathrm{Kg}$, dan akan mengalami peningkatan pada saat akhir minggu atau menuju libur kuliah.

Jumlah karyawan di Laundry Zone ini adalah lima belas orang dengan pembagian kerja yang tegas. Dalam satu shift terdapat tiga macam kelompok tugas dengan tanggung jawab yang berbeda. Kelompok pertama akan bertugas di 
bagian produksi (mencuci, dan mengeringkan), kelompok kedua akan bertugas dalam menyetrika dan membungkus pakaian, sedangkan kelompok ketiga akan bertugas ke dalam meletakkan pakaian yang sudah bersih ke dalam rak penyimpanan dan bertugas untuk melayani konsumen yang datang untuk mengambil atau menyerahan pakaian. Jumlah pekerja yang berada di bagian setrika atau kelompok kedua adalah enam orang orang, dua orang akan bekerja pada kelompok tiga dan satu orang akan bekerja pada kelompok satu. Pekerjaan menyetrika merupakan pekerjaan yang paling berat dalam bisnis laundry. Pekerja harus memperhatikan dengan cermat bahan yang disetrika dan tingkat wewangian yang diinginkan oleh konsumen. Bagian setrika juga merupakan salah satu bagian dalam bisnis laundry yang murni mengandalkan kemampuan manusia. Jumlah pekerja yang banyak akan mengurangi tingkat stres yang dihadapi oleh pekerja, setiap pekerja dapat bekerja dan berinteraksi dengan sesama pekerja. Pekerja di bagian produksi tidak akan mengalami hal tekanan yang tinggi, karena bantuan dari mesin cuci membuat pekerjaan mereka menjadi lebih ringan. Namun tetap saja kehati-hatian dalam memperlakukan pakaian konsumen harus menjadi fokus utama dari setiap pekerja yang ada di kelompok manapun.

Berbeda dengan Laundry Zone UII yang mensyaratkan dua orang karyawan untuk hadir setiap harinya, di Laundry Zone Seturan ini karyawan di jadwalkan untuk hadir sesuai dengan jadwal yang telah dibuat, dan jumlah pegawai akan semakin meningkat pada siang hari dan kembali menyusut pada saat malam hari. Hal ini disesuaikan dengan kondisi pasar, konsumen akan menumpuk pada siang hari dan berkurang pada malam hari di atas pukul 7 malam.

Penjadwalan yang menaruh karyawan dalam jumlah yang sama di setiap shift akan membuat perusahaan kurang responsif dalam melayani konsumen. Kurang responsif yang dimaksud adalah jumlah karyawan yang ada lebih banyak daripada jumlah pekerjaan yang masuk pada saat itu. Dengan mempekerjakan pekerja yang lebih banyak, biaya pekerja akan menjadi salah satu aspek yang mengalami penggelembungan, apalagi bila jumlah pekerjaan yang ada tidak sesuai. Selain itu dengan menaruh jumlah karyawan yang sama, maka akan dibutuhkan karyawan yang berbeda posisi untuk tiga shift yang berarti penumpukan jumlah karyawan. Akan dibutuhkan kasir sebanyak tiga orang untuk tiga shift, dan akan dibutuhkan pekerja produksi yang sesuai untuk bekerja dalam tiga shift yang berbeda.

Sebagai sebuah usaha kecil, biaya merupakan salah satu hal yang menjadi pertimbangan bagi pemilik laundry dalam menjalankan aktivitas bisnisnya. Peningkatan biaya karyawan akan menjadikan harga yang harus dibayarkan oleh konsumen menjadi semakin mehal, dan dengan jumlah usaha laundry yang semakin banyak, faktor harga menjadi salah satu faktor perhatian konsumen walaupun bukan faktor yang dominan.

Dengan menumpuk karyawan pada jam yang jumlah konsumennya menumpuk, akan membuat setiap pesanan yang masuk dapat dikerjakan dengan cepat dan keputusan akan waktu selesainya sebuah pekerjaan dapat ditentukan dengan lebih baik. Salah satu layanan yang menjadi primadona di Laundry Zone adalah layanan kilat yang akan menyelesaikan cucian dalam waktu dua belas jam dari waktu penyerahan pakaian. Dengan memberikan layanan kilat, maka jumlah karyawan dan juga ketersediaan sumberdaya yang lain wajib diperhatikan dengan baik, karena hal ini akan berdampak pada kepuasan konsumen. Layanan kilat akan menyebabkan rangkaian pekerjaan yang sudah terjadwal akan mengalami sedikit penundaan, meskipun penundaan tersebut tidak lama tetapi penggunaan kapasitas dan juga beban kerja setiap karyawan akan mengalami peningkatan. Kesalahan perhitungan akan menyebabkan beban kerja yang berlebih namun tidak mampu untuk ditangani dan pada akhirnya akan menyebabkan konsumen kecewa.

Layanan kilat yang diberikan menjadikan Laundry Zone berbeda dengan laundry yang lain, oleh sebab itulah layanan ini tetap dipertahankan. Konsumen akan membayar dua kali lipat dari layanan biasa, dan biasanya pengguna layanan kilat adalah mahasiswa atau pekerja yang memiliki seragam khusus yang dipakai setiap kali beraktifitas dan menemukan bahwa pakaian tersebut sudah selayaknya dicuci. Komposisi pengguna layanan kilat dibandingkan dengan pengguna layanan biasa saat ini hanya berkisar $15 \%$ per bulan dari total jumlah pekerjaan yang ditangani setiap bulannya. Setiap bulannya 
Laundry Zone mengerjakan cucian kurang lebih sebanyak lima ribu hingga enam ribu kilogram. Jumlah cucian yang banyak ini dimungkinkan karena letak Laundry Zone yang berdekatan dengan beberapa kampus swasta seperti YKPN, Atma Jaya, dan Sanata Dharma. Selain itu wilayah Seturan menjadi sentra bagi mahasiswa untuk melakukan aktifitas seperti olahraga dan makan. Di daerah Seturan dapat dijumpai berbagai macam warung makan, cafe, tempat belanja, dan toko baju. Namun jumlah laundry yang terletak di daerah tersebut relatif jarang, dan hanya terdapat satu laundry yaitu Laundry Zone yang akan memudahkan mahasiswa untuk mencuci baju.

Jadwal karyawan Laundry Zone Seturan dan pembagiannya dapat dilihat dalam tabel $1 \mathrm{di}$ bawah ini. Tabel 1 menunjukkan pembagian jumlah karyawan dalam setiap shift per harinya. Jumlah pekerja yang ada dalam setiap shift ditentukan berdasarkan pengalaman, pekerjaan akan mengalami peningkatan pada saat siang hari, proses pengambilan pakaian oleh konsumen akan lebih sering dilakukan pada sore hari hingga menjelang pukul delapan malam.

Tabel 1 Alokasi Karyawan Laundry Zone Seturan

\begin{tabular}{|l|c|c|c|}
\hline & \multicolumn{3}{|c|}{ Shift } \\
\hline Hari & I & II & III \\
\hline Senin & 3 & 9 & 3 \\
\hline Selasa & 3 & 9 & 3 \\
\hline Rabu & 3 & 9 & 3 \\
\hline $\begin{array}{l}\text { Kami } \\
\text { s }\end{array}$ & 3 & 9 & 3 \\
\hline Jumat & 3 & 9 & 3 \\
\hline Sabtu & 3 & 9 & 3 \\
\hline $\begin{array}{l}\text { Ming } \\
\text { gu }\end{array}$ & 3 & 9 & 3 \\
\hline
\end{tabular}

Sumber: Laundry Zone

Tabel 2 Jam Kerja

\begin{tabular}{|c|c|}
\hline Shift & Waktu \\
\hline I & $07.00-14.00$ \\
\hline II & $14.00-22.00$ \\
\hline III & $22.00-07.00$ \\
\hline IV & PIKET \\
\hline
\end{tabular}

Sumber: Lundry Zone

Dari tabel 2 dapat diketahui bahwa karyawan akan dikonsentrasikan pada shift kedua, karena pada shift kedua yaitu pada pukul delapan pagi hingga pukul dua siang jumlah konsumen mengalami peningkatan. Pekerja lakilaki akan lebih banyak mendapatkan shift sore atau malam, hal ini dikarenakan pada waktu tersebut konsumen tidak terlalu banyak sehingga jumlah pekerjaan juga tidak terlalu menumpuk, dan juga untuk faktor keamanan. Pekerja wanita yang bekerja pada shift sore atau malam jumlahnya hanya satu orang, dua sisanya adalah pekerja laki-laki. Setiap pekerja akan selalu berada dalam shift yang sama, tidak terdapat rotasi pekerja. Hal ini dilandasi oleh pemikiran bahwa setiap shift adalah sebuah tim dan semakin lama anggota tim bekerja bersama maka akan semakin bagus kinerja dari tim tersebut.

Dengan sistem seperti yang disebutkan di atas, permasalahan yang mungkin timbul adalah pada saat terdapat pekerja yang berhalangan untuk masuk kerja, maka jumlah pegawai yang akan menangani pekerjaan yang ada menjadi berkurang. Pergantian oleh pekerja yang lain sulit untuk dilakukan, karena pekerja pengganti akan bekerja selama enambelas jam berturut-turut dan hal tersebut merupakan masalah besar karena bisa jadi motivasi dan energi dari pekerja yang bersangkutan menjadi menurun. Penurunan motivasi dan juga energi akan menyebabkan pekerjaan yang dilakukan menjadi kurang maksimal, dan hal ini bisa jadi memicu ketidak puasan konsumen. Dalam bidang jasa suara konsumen merupakan aset yang berharga, karena dengan suara konsumen pula sebuah perusahaan jasa akan dapat menjaring konsumen.

Dengan membentuk sebuah tim, sebuah pekerjaan akan menjadi cepat terselesaikan. Setiap anggota tim akan mengetahui perilaku dari teman setimnya dalam bekerja yang akan membuat rasa toleransi setiap anggota tim meningkat. Namun yang perlu diperhatikan adalah keseimbangan dari tim tersebut pada saat sesuatu yang tidak diduga terjadi. Penjadwalan yang saat ini dilakukan memang memberikan keuntungan pada stabilitas dan pemenuhan deadline pekerjaan, hal ini akan terpenuhi dengan asumsi bahwa anggota tim jumlahnya lengkap. Beban kerja yang relatif tinggi, deadline pekerjaan yang sempit, dan tanggung jawab terhadap bidang kerjanya yang menuntut ketelitian menjadikan setiap pekerja harus mencurahkan setiap perhatiannya dengan baik.

Hari libur karyawan tidak menjadi 
sebuah agenda khusus dalam siklus kerja dari masing-masing karyawan. Tidak adanya jadwal khusus bagi libur karyawan ini dikarenakan setiap karyawan hanya bekerja selama delapan jam setiap harinya, sedangkan enambelas jam sisanya bisa digunakan untuk memulihkan energi dan juga melakukan hal lain bagi karyawan. Hari besar dan libur nasional akan dijadikan hari libur bagi karyawan, sebelum melakukan libur bersama, pihak Laundry Zone akan memberitahukannya kepada konsumen sehingga konsumen akan siap dengan penutupan sementara tersebut.

Permasalahan yang timbul di Laundry Zone adalah tingkat turn over karyawan yang tinggi. Rata-rata karyawan hanya mampu bekerja selama empat bulan sebelum akhirnya memutuskan untuk keluar dari pekerjaannya. Tingkat turn over yang tinggi tersebut disebabkan tuntutan yang tinggi dalam menjaga setiap pakaian yang dicuci, karena setiap pakaian yang hilang akan menyebabkan karyawan yang bersangkutan akan dipotong gajinya. Pemotongan gaji ini dirasa berat bagi karyawan, selain itu pemotongan tersebut tidak dibebankan kepada satu orang saja namun kepada seluruh anggota tim yang menangani pekerjaan yang bersangkutan.

Dengan desain penjadwalan yang kurang memberikan kesempatan kepada semua karyawan untuk merasakan bekerja pada setiap shift yang ada, kesan eksklusif akan muncul dan akan membuat karyawan yang ada merasa kurang termotivasi untuk bekerja karena terdapat kesenjangan kelompok di dalam orgaisasi tersebut. Metode penjadwalan Cyclical akan membuat setiap pekerja mendapatkan jatah yang sama dalam bekerja tanpa peduli akan kepentingan pribadi dari pekerja yang bersangkutan. Untuk menerapkan metode siklis ini, perusahaan dapat memberikan pilihan kepada karyawannya untuk bekerja pada shift yang populer namun dengan gaji atau bonus yang biasa saja atau bekerja pada shift yang tidak populer namun dengan pendapatan dan bonus yang sedikit lebih banyak dibandingkan dengan shift yang populer (Maenhout et al, 2006). Penumpukan jumlah karyawan yang ada pada shift siang hari akan membuat pekerjaan pada malam dan pagi hari menjadi kurang efektif. Akan lebih baik apabila jumlah karyawan yang ada disesuaikan dengan jumlah pekerjaan yang mungkin akan masuk pada shift yang bersangkutan. Apabila dibentuk ke dalam metode cyclical maka penjadwalan karyawan di laundry zone Seturan akan menjadi seperti di bawah ini

Tabel 3 Kebutuhan Pekerja Minimum

\begin{tabular}{|l|c|c|c|c|c|c|c|}
\hline & $\begin{array}{c}\text { Sen } \\
\text { in }\end{array}$ & $\begin{array}{c}\text { Sela } \\
\text { sa }\end{array}$ & $\begin{array}{c}\text { Ra } \\
\text { bu }\end{array}$ & $\begin{array}{c}\text { Ka } \\
\text { mis }\end{array}$ & $\begin{array}{c}\text { Jum } \\
\text { at }\end{array}$ & $\begin{array}{c}\text { Sabt } \\
\text { u }\end{array}$ & $\begin{array}{c}\text { Ming } \\
\text { gu }\end{array}$ \\
\hline Shift I & 2 & 2 & 2 & 2 & 2 & 4 & 4 \\
\hline Shift II & 10 & 10 & 10 & 10 & 10 & 10 & 11 \\
\hline $\begin{array}{l}\text { Shift } \\
\text { III }\end{array}$ & 2 & 2 & 2 & 2 & 2 & 3 & 3 \\
\hline
\end{tabular}

Sumber: Laundry Zone

Tabel 4. Sistem Penjadwalan Lama

\begin{tabular}{|c|c|c|c|c|c|c|c|}
\hline & $\begin{array}{c}\text { Se } \\
\text { nin }\end{array}$ & $\begin{array}{c}\text { Sel } \\
\text { asa }\end{array}$ & $\begin{array}{c}\text { Ra } \\
\text { bu }\end{array}$ & $\begin{array}{c}\text { Ka } \\
\text { mis }\end{array}$ & $\begin{array}{c}\text { Ju } \\
\text { mat }\end{array}$ & $\begin{array}{c}\text { Sa } \\
\text { btu }\end{array}$ & $\begin{array}{c}\text { Ming } \\
\text { gu }\end{array}$ \\
\hline Pekerja 1 & I & I & I & I & I & I & I \\
\hline Pekerja 2 & I & I & I & I & I & I & I \\
\hline Pekerja 3 & I & I & I & I & I & I & I \\
\hline Pekerja 4 & II & II & II & II & II & II & II \\
\hline Pekerja 5 & II & II & II & II & II & II & II \\
\hline Pekerja 6 & II & II & II & II & II & II & II \\
\hline Pekerja 7 & II & II & II & II & II & II & II \\
\hline Pekerja 8 & II & II & II & II & II & II & II \\
\hline Pekerja 9 & II & II & II & II & II & II & II \\
\hline Pekerja 10 & II & II & II & II & II & II & II \\
\hline Pekerja 11 & II & II & II & II & II & II & II \\
\hline Pekerja 12 & II & II & II & II & II & II & II \\
\hline Pekerja 13 & III & III & III & III & III & III & III \\
\hline Pekerja 14 & III & III & III & III & III & III & III \\
\hline Pekerja 15 & III & III & III & III & III & III & III \\
\hline
\end{tabular}

Sumber: Laundry Zone

Dari tabel 4 di atas angka romawi satu menunjukkan bahwa pekerja yang bersangkutan akan bekerja dalam shift pertama, dan angka romawi dua menunjukkan bahwa pekerja yang bersangkutan akan bekerja pada shift kedua begitu pula dengan angka romawi tiga menunjukkan bahwa pekerja yang bersangkutan akan bekerja pada shift ketiga. Dari tabel 4 pula dapat dilihat bahwa susunan pekerja yang ada kurang mampu menutupi kebutuhan minimum pekerja seperti yang tampak pada tabel 3 Pekerja yang dikonsentrasikan pada shift kedua yang berjumlah sembilan orang hanya tepat menutup kebutuhan akan pekerja selama tiga hari saja, sedangkan empat hari sisanya terjadi kekurangan pekerja. Dari tabel 3 pula dapat dilihat bahwa dalam setiap shift masalah kurang tepatnya alokasi pekerja dengan beban pekerjaan masih terjadi. Untuk mengatasi hal tersebut maka 
penjadwalan siklis dapat menjadi salah satu alternatif pemecahan masalah ini, adapun penjadwalan siklis yang bisa dilaksanakan dalam Laundry Zone Seturan adalah sebagai berikut:

Tabel 5 Sistem Penjadwalan Siklis

\begin{tabular}{|l|c|c|c|c|c|c|c|}
\hline & $\begin{array}{c}\text { Se } \\
\text { nin }\end{array}$ & $\begin{array}{c}\text { Sela } \\
\text { sa }\end{array}$ & $\begin{array}{c}\text { Ra } \\
\text { bu }\end{array}$ & $\begin{array}{c}\text { Ka } \\
\text { mis }\end{array}$ & $\begin{array}{c}\text { Jum } \\
\text { at }\end{array}$ & $\begin{array}{c}\text { Sab } \\
\text { tu }\end{array}$ & $\begin{array}{c}\text { Ming } \\
\text { gu }\end{array}$ \\
\hline Pekerja 1 & I & I & I & I & I & I & I \\
\hline Pekerja 2 & I & I & I & I & I & I & I \\
\hline Pekerja 3 & I & I & I & I & I & I & I \\
\hline Pekerja 4 & II & II & II & II & II & II & II \\
\hline Pekerja 5 & II & II & II & II & II & II & II \\
\hline Pekerja 6 & II & II & II & II & II & II & II \\
\hline Pekerja 7 & II & II & II & II & II & II & II \\
\hline Pekerja 8 & II & II & II & II & II & II & II \\
\hline Pekerja 9 & II & II & II & II & II & II & II \\
\hline Pekerja 10 & II & II & II & II & II & II & II \\
\hline Pekerja 11 & II & II & II & II & II & II & II \\
\hline Pekerja 12 & II & II & II & II & II & II & II \\
\hline Pekerja 13 & II & II & II & II & II & III & III \\
\hline Pekerja 14 & III & III & III & III & III & III & III \\
\hline Pekerja 15 & III & III & III & III & III & III & III \\
\hline $\begin{array}{l}\text { Kekurang } \\
\text { an }\end{array}$ & 0 & 0 & 0 & 0 & 0 & 2 & 3 \\
\hline
\end{tabular}

Sumber: Laundry Zone

Dari tabel 5 dengan melakukan penjadwalan siklis kekurangan pegawai hanya terjadi pada Sabtu dan Minggu saja. Kekurangan pegawai ini dapat diatasi dengan dua cara, pertama adalah merekrut tenaga kerja tambahan atau cara kedua dengan merekrut tenaga kerja yang sudah ada namun dengan memberikan jam kerja tambahan. Tabel 5 disusun untuk mengatur jadwal kerja selama satu minggu saja, maksimal pelaksanaan jadwal kerja ini adalah satu bulan. Hal ini dikarenakan adanya tuntutan kesetaraan untuk merasakan bekerja pada lingkungan dan waktu yang berbeda bagi setiap pegawai yang ada. Dengan memberikan kesempatan yang sama kepada setiap pekerja untuk merasakan berada dalam shift yang populer maka kekompakan tim akan semakin meningkat, tidak ada seorang pekerja yang merasa menjadi pekerja yang paling berjasa dan yang lebih penting adalah bahwa setiap pekerja memiliki pilihan untuk menghasilkan uang yang lebih banyak dengan bekerja pada shift yang tidak populer.

\section{KESIMPULAN DAN SARAN Kesimpulan}

Adapun kesimpulan yang dapat ditarik dari penelitian ini adalah sebagai berikut:
1. Beban kerja harian yang ditangani oleh pekerja di Laundry Zone Condong Catur adalah sebesar $80 \mathrm{Kg}$ pada hari Senin sampai Jumat sedangkan pada hari Sabtu dan Minggu jumlah pekerjaan yang harus ditangani meningkat menjadi $120 \mathrm{Kg}$, dan pembagian beban kerja seringkali tidak merata akibat dari pengambilan waktu libur oleh karyawan yang tidak sesuai dengan kondisi permintaan yang ada saat itu. Sedangkan beban kerja yang harus ditangani oleh pekerja di Laundry Zone Seturan adalah sebesar $1500 \mathrm{Kg}$ sampai 2300 $\mathrm{Kg}$ dan pada akhir minggu akan mengalami peningkatan hingga $4800 \mathrm{Kg}$.

2. Setelah di implementasikan sistem penjadwalan siklis, jumlah pekerjaan yang harus di tangani oleh pekerja menjadi semakin merata. Semakin meratanya pekerjaan yang harus ditangani oleh seorang pekerja bisa terjadi karena penjadwalan siklis mampu mengatur jadwal masuk karyawan disesuaikan dengan jumlah demand atau pekerjaan yang masuk.

3. Dengan sistem penjadwalan siklis, pekerja akan masuk kerja sesuai dengan waktu yang telah tercantum dalam jadwal. Jadwal kerja yang selama ini tidak ada, sekarang menjadi ada dan dimungkinkan untuk dirubah sesuai dengan kondisi pasar, hal ini menjadikan perusahaan semakin responsif dalam menghadapi persaingan dengan perusahaan lain.

4. Dari sisi strategi penjualan, Laundry Zone menetapkan strategi pengiriman yang cepat. Hasil cucian bisa diambil oleh konsumen selang dua puluh empat jam dari waktu memasukkan cucian ke laundry. Dengan strategi ini, diharapkan konsumen yang berstatus pelajar atau mahasiswa akan menjadi konsumen tetap dari Laundry Zone. Ditambah dengan pemberian harga yang relatif murah dengan jaminan penggantian pakaian rusak sebesar seratus persen, akan menjadikan Laundry Zone sebagai sebuah laundry mahasiswa dengan fasilitas laundry kelas atas.

\section{Saran}

1. Agar setiap gerai menetapkan standar penjadwalan yang sama, sehingga pelayanan yang diberikan akan seragam. Saat ini antara gerai induk dengan gerai waralaba memiliki 
perbedaan. Perbedaan yang tampak adalah pada waktu operasional dari setiap gerai. Padahal sebagai sebuah kesatuan, dan memungkinkan bagi satu gerai untuk memindahkan pekerjaan yang ada ke gerai lain, jam operasional yang sama adalah salah satu hal penting agar konsumen dapat mengambil pakaian sesuai dengan waktu yang telah dijanjikan.

2. Agar setiap karyawan memahami kepentingan perusahaan daripada mengutamakan kepentingan pribadinya. Selama ini banyak karyawan yang lebih mengutamakan kepentingan pribadinya dibandingkan dengan kepentingan perusahaan. Pada saat jumlah pekerjaan menumpuk seringkali jumlah karyawan tidak memadai.

3. Agar perusahaan lebih memperhatikan penjadwalan yang dibuat dengan lebih seksama. Saat ini dengan sistem penjadwalan lama, perusahaan mengalokasikan sepuluh hari untuk libur karyawan yang hal tersebut bisa dimanfaatkan untuk bekerja dan mencari uang bagi karyawan yang bersangkutan.

4. Penjadwalan siklis akan membuat pekerja dan jumlah pekerjaan seimbang, walaupun begitu perbaikan sistem gaji juga harus diperhatikan karena sistem penjadwalan yang baik tidak akan memiliki arti pada saat sistem yang lain kurang mendukung.

5. Alangkah lebih baik bila kapasitas yang ada saat ini dikembangkan, karena pekerja yang ada sudah mulai kewalahan dalam menjalankan aktivitas pekerjaannya.

\section{DAFTAR PUSTAKA}

Anthony, Robert N., and Vijay Govindarajan, 2007, Management Control System, McGraw Hill, New York.

Besanko et al, Economics of Strategy, 2007, John Wiley and Sons.

Chase, R.B., N.J. Aquilano and F.B. Jacobs, 2006, Production and Operations Management: Manufacturing and Services, McGraw Hill.

Cooper, Donald R. and Pamela S. Schindler, 2006, Metode Riset Bisnis, McGraw Hill, New york.
Herjanto, Eddy, Manajemen Operasi, 2007, Grasindo, Jakarta.

Heizer, Jay and Barry Render, 2006, Operation Management, Prentice Hall, New Jersey.

Kotler, Phillip and Kevin Lane Keller, 2006, Marketing Management, Prentice Hall, New York.

Krajweski et al, 2002, Operation Management, Pearson Education.

Lovelock, Christopher and Lauren Wright, 2002, Principles of Service Marketing and Management, McGraw Hill, New York.

Maenhout, Broos and Mario Vanhoucke, January 2006, The Impact of Incorporating NurseSpecific Characteristic in a Cyclical Scheduling Approach, Working Paper, Universiteit Gent.

Pinedo, Michael and Xiuli Chao, 1999, Operations Scheduling With Application in Manufacturing and Services, Irwin McGraw Hill, Singapore. 